\title{
Maxillary removable partial denture combined with O’ring attachment implant: a case report
}

\begin{abstract}
- Tiago Rebelo Costa Departament of Prosthodontics, School of Dentristry, University of São Paulo, São Paulo, SP, Brazil • Cláudio Akira Yamaguchi Departament of Prosthodontics, School of Dentristry, University of São Paulo, São Paulo, SP, Brazil • Alessandra Pucci Mantelli Galhardo Departament of Prosthodontics, School of Dentristry, University of São Paulo, São Paulo, SP, Brazil • Roberto Chaib Stegun Departament of Prosthodontics, School of Dentristry, University of São Paulo, São Paulo, SP, Brazil • Bruno Costa Departament of Prosthodontics, School of Dentristry, University of São Paulo, São Paulo, SP, Brazil • Márcio Katsuyoshi Mukai Departament of Prosthodontics, School of Dentristry, University of São Paulo, São Paulo, SP, Brazil
\end{abstract}

ABSTRACT | Oral rehabilitation with free-end removable partial denture (RPD) is one of the major challenges in prosthodontic dentistry. The absence of a distal abutment produces undesirable RPD movement during masticatory function due to the high resilience of the residual ridge, which limits the denture efficiency and may damage the abutment teeth and bone over time. The advent of dental implants made possible to substitute the missing teeth with fixed implant-supported dentures as the first choice treatment to overcome such inconveniences. However, this indication may not be suitable for all patients due to financial, anatomical or systemic health conditions. Nevertheless it is possible to improve free extension RPD by using implants in the posterior edentulous ridge to achieve biological, biomechanical, physiological and social benefits. This article aims to present a case report on oral rehabilitation in which a RPD was made combined with an implant for posterior support in a sizeable edentulous ridge. The patient appreciated the retention improvement and the aesthetic result. The combination of a RPD with a posterior implant is an alternative treatment for cases in which implant-supported fixed prosthesis is not indicated, reducing the displacement and minimizing the limitations of the free-end devices.

DESCRIPTORS | Case report; Dental Implants; Oral rehabilitation.

RESUMO | Utilização de implante com encaixe tipo o'ring associado à prótese parcial removível - relato de caso • A reabilitação por meio de prótese parcial removível (PPR) para os casos de extremidade livre distal é um dos grandes desafios da reabilitação oral. A ausência de pilar posterior promove maior movimentação da PPR durante a função, devido à resiliência da fibromucosa. Com o advento dos implantes, esses passaram a ser a primeira alternativa de tratamento para arcos com essa configuração. Entretanto, nem todos os casos podem se beneficiar dessa indicação, considerando as condições financeiras, estruturais ou de ordem sistêmica do paciente. Para melhorar o suporte posterior da PPR, é possível associá-la aos implantes no espaço edentado, buscando benefícios biológicos, biomecânicos, sociais e fisiológicos. Nesse sentido, o objetivo desse trabalho é apresentar um caso clínico utilizando implante conjugado com PPR na reabilitação de um espaço edentado considerado grande. Ao final, a paciente se mostrou satisfeita com a estética e melhora da retenção. Portanto, a associação de PPR com implante é uma alternativa de tratamento aos pacientes que não podem ser submetidos a próteses fixas implanto suportadas, além de proporcionar a redução do deslocamento da extremidade livre desses aparelhos.

DESCRITORES | Relato de caso; Implantes dentários; Reabilitação oral.

CORRESPONDING AUTHOR | • Tiago Rebelo Costa Departament of Prosthodontics, School of Dentistry, University of São Paulo • Av. Professor Lineu Prestes, 2227 São Paulo, SP, Brazil • 05508-000 E-mail: tiago.rebelo@ymail.com

- Received Apr 10, 2017 • Accepted May 24, 2017

- Dol http://dx.doi.org/10.11606/issn.2357-8041.clrd.2018.129422 


\section{INTRODUCTION}

To rehabilitate large edentulous ridges using removable partial dentures (RPD) is a complex task considering the biomechanics involved. Such complexity is mainly due to the changes in the residual ridge over time and the different tissue resiliences between the abutment teeth and the edentulous ridge mucosa. During masticatory function, as the soft tissue of the mucosa yields more under load stress than the remaining teeth, the RPD ultimately exerts undesirable stress over the periodontal supporting tissues of the abutment teeth. ${ }^{1}$ To better control and distribute the masticatory load among the teeth and the residual ridge tissues, a functional impression must be made to extend the denture base within the physiological limits of each patient. Also, the incorporation of clasps or attachments and periodic rebasing of the prosthetic base is recommended. ${ }^{2}$

Implants are considered the best prosthetic treatment due to their stability, aesthetics and capacity of preserving the periodontal tissues of the remaining teeth and the alveolar ridge bone. Despite these advantages, it cannot be applied to all patients because of high cost, limitations of oral structures or compromised systemic health.

The absence of a posterior support is a complex biomechanical situation for the RPD function. ${ }^{3}$ When the treatment is not well planned or executed, damages to the oral remaining structures may occur. A good treatment plan must avoid injuries to the supporting tissues. Using a combined tooth and implant-supported RDP allows the placement of fewer implants when compared to an implantsupported fixed denture, which makes the first alternative financially more feasible than the latter. On the other hand, it provides better stability during function than the conventional RPD. Thus, modifying the Kennedy classification by inserting an implant as a posterior pillar prevents bone resorption, allows clasp removal from aesthetical areas and reduces the load over the abutment teeth. ${ }^{4}$ Many authors report successful cases associating RPD with implants. ${ }^{1}$

This article aims to present and discuss a case of maxillary RPD associated with an implant, proposing it as an alternative treatment which increases the denture retention and stability and provides aesthetic gain, confirmed by the patient's approval.

\section{CASE REPORT}

Patient MAVD, 43, came to FUNDECTO the continuing education program of USP School of Dentistry - searching for dental care at the Oral Rehabilitation Clinic. Her complaints were retention and aesthetic problems in her current dentures. Clinical examination showed absence of teeth 12 to 17,21 and 27 in the upper arch, and $35,36,37,46$ and 47 in the lower arch. Conventional RPDs were replacing the absent teeth (Figure 1).

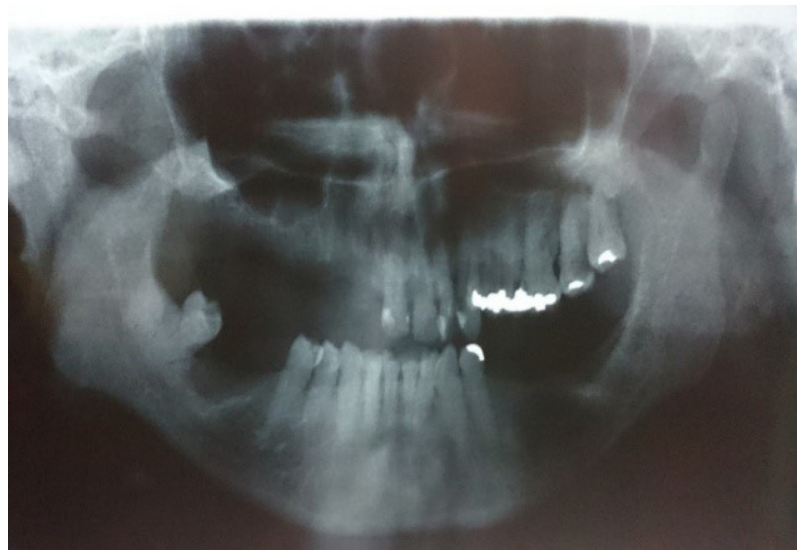

Figure 1 | Panoramic radiography showing the beginning

Three options for treatment were proposed for the upper dental arch: fixed partial implant-supported prosthesis, RPD combined with an o'ring attachment over one implant, and conventional RPD. A new conventional RPD was suggested for the mandibular dental arch. Due to anatomical and financial limitations, the patient chose the second alternative for the maxillary denture (Figure 2; Figure 3). 


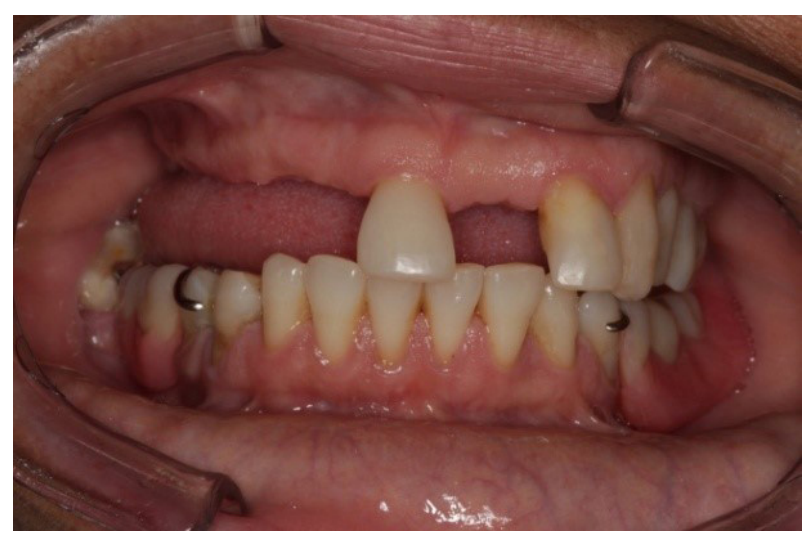

Figure 2 | Initial Case: Rehabilitation of the inferior arc using conventional RPD

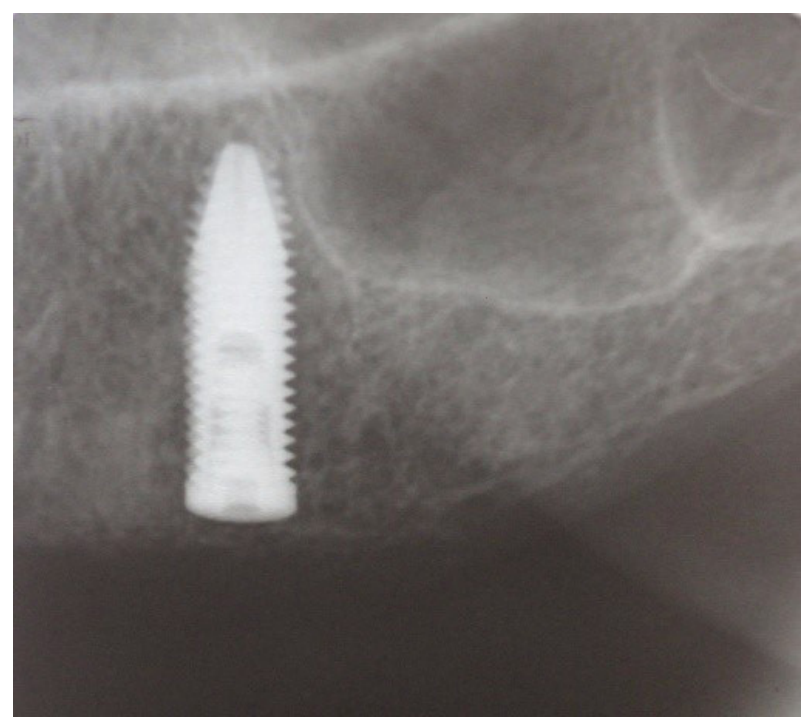

Figure 3 | Radiography showing implant position (Titamax Ex $\left.\mathrm{CM}-\mathrm{Neodent}{ }^{\circledR}\right)$ and its relation to the maxillary sinus.

Thus, the lower arch received a new conventional RPD and the upper arch received a RPD combined to an implant (Figure 1). The rehabilitation process of the maxillary arch is described here.

The region selected to receive the implant was determined by the analysis of the biomechanical factors that would affect the prosthesis behaviour in function. Selecting the best position followed some criteria: to minimize the leverage at the denture free end, avoid complex surgeries such as bone grafts, and eliminate tooth 11 retention clasp. The decision to place the implant in the area corresponding to tooth 13 aimed to strengthen the dental arch curvature where the load incidence is high, taking advantage of the bone support offered by the canine pillar.

The patient's medical background did not reveal any systemic condition that prevented the implant placement surgery. Surgical antibiotic prophylaxis was done by administrating 2 capsules of Amoxicilin $500 m$ one hour before the procedure, followed by $500 m$ at 8 hour intervals for 7 days. The selected implant was the Titamax EX CM NEODENT $®$ $3.75 \mathrm{~mm} \times 13 \mathrm{~mm}$. The surgery was performed under local anesthesia. The incision was made in the alveolar bone crest at the right upper canine region. A full thickness flap was folded to expose the bone, and bone drilling and implant placement were performed according to manufacturer's instructions. ${ }^{5}$ Surgical cover screw was placed and the gingival flap was repositioned and sutured. The surgery was uneventful. Three months were given for the implant osteointegration.

After the implant reopening surgery, a transmucosal healing collar was placed for the soft tissue to adapt. Planning the RPD design and preparation of the abutment teeth were performed after the analysis of the study cast on the dental surveyor. The RPD structure was built considering the implant position. A metallic reinforcement was made near the implant region to prevent acrylic fracture (Figure 4).

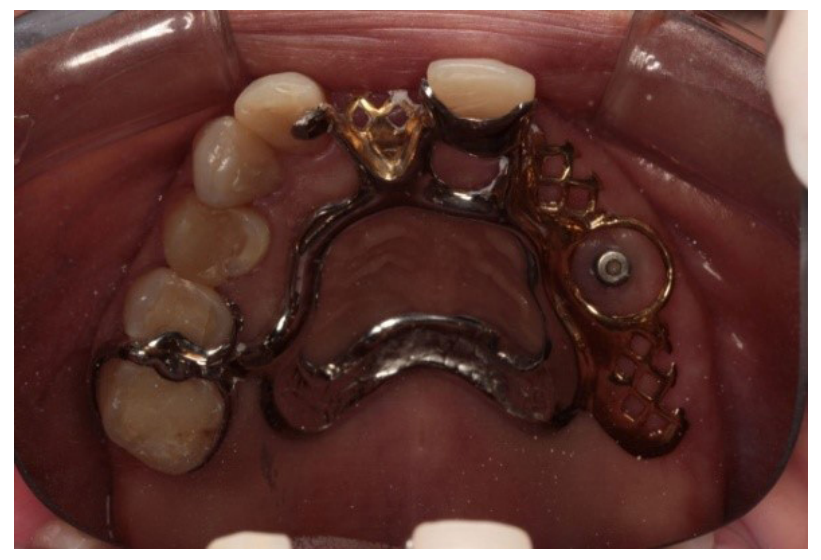

Figure 4 | Proof of the metallic structure. 
After the trial denture approval, the RPD was finished and delivered. The patient wore the RPD for 2 weeks while the required adjustments were done.

When the RPD was properly adjusted and fit, the procedures for the attachment addition were carried out. The capture of the attachment was made intraorally. The healing collar was removed and replaced by a $2.5 \mathrm{~mm}$ Neodent $\AA$ mini ball attachment, installed with a torque of $32 \mathrm{Ncm}$. The transmucosal depth was determined by using a periodontal depth probe, also considering the healing collar that was used. The O'ring housing was positioned over the mini ball attachment along with a protection pick up disk supplied by the manufacturer to prevent acrylic resin to leak into retentive areas around the attachment and the prosthesis during the pick up. The intaglio surface of the denture base was drilled out over the attachment position to allow a free fit of the RPD around the attachment. Autopolymerizing acrylic resin was poured into the pick-up space and the denture was placed over the abutment. During resin polymerization the patient was maintained in occlusion to avoid any change in maxillomandibular relation. Fit and occlusion were rechecked after trimming and polishing the denture.

The new maxillary prosthesis met the patient's expectations, and the concerns regarding aesthetics and retention were solved (Figure 5).

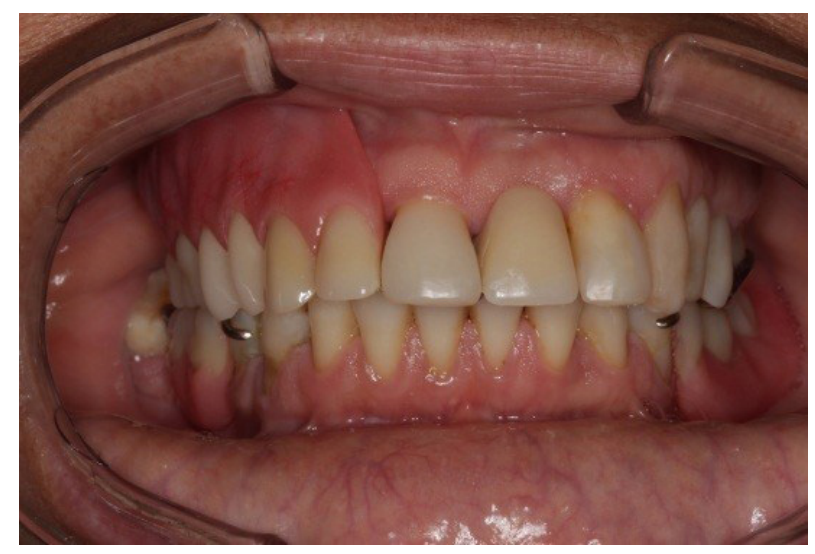

Figure 5 || End of the Case: Implanted RPD.

\section{DISCUSSION}

Rehabilitation of free-end cases with RPD poses a major challenge for the dentist who aims to restore oral aesthetics, comfort and function. Since this kind of prosthesis is sustained both by hard and soft tissues, the difficulty comes from the differences in the supporting tissues behavior, compromising the support and stability of the denture. The residual ridge tissue yields more under compression than the periodontal ligament of the supporting teeth does. Under masticatory pressure, the residual ridge mucosa undergoes a displacement of 350-500 $\mu \mathrm{m}$ while the tooth intrusion movement submitted to the same load yields $20 \mu \mathrm{m} .{ }^{6}$ As the masticatory load is applied, the higher displacement of the residual ridge creates a rotational movement of the freeend denture over a fulcrum located at the occlusal rest of the most distal abutment tooth, generating torque on this pillar tooth. The larger the free-end, the larger the lever arm which causes the prosthesis to rotate, and the higher the torque on the abutment tooth, causing quicker alveolar bone resorption.?

Since the $19^{\text {th }}$ century remaining posterior teeth roots have been strategically used to favor RPD biomechanics. They may be used to anchor attachments or just function as a support for vertical loads. The historical good results achieved with this conduct allied to the more recent development of implant dentistry led to the association of these elements to produce a treatment alternative to the conventional RPD, which can effectively improve the denture stability and retention and prevent alveolar ridge resorption. ${ }^{1}$

According to Kuzmanovic et al. ${ }^{8}$ using implants in the distal region of the residual ridge in cases of uni- or bilateral free-ends, Kennedy class I and II respectively, changes the denture biomechanics since the situation changes from a dento-mucoussupported prosthesis to a dento-implant-supported one. The latter would behave similarly to a Kennedy class III rehabilitation. 
Some authors defend that such association protects pillar teeth since they would be submitted to less load concentrations. ${ }^{1,3}$ Verri et al., ${ }^{9}$ in their studies on finite elements, do not observe the occurrence of diminished stress over the abutment teeth in similar conditions.

Gonçalves et al. ${ }^{10}$ measured the masticatory efficiency and the maximum bite force in patients who had only the lower front teeth (canines and incisors). The patients were treated either with a traditional RPD, a RPD combined with implants, or fixed dentures over implants. They verified an increase of $79 \%$ in the maximum bite force and an increase of $91 \%$ in the capability of grinding food in patients who received the RPD-implant combination when compared to the conventional RPD rehabilitation.

An important question to be answered is: which is the best attachment system to be combined with a RPD? Most of the studies use the o'ring type or just a transmucosal abutment without retention to neutralize occlusal-cervical loads.

Despite these controversies, there is an overall understanding that combined RPD-distal implantsupported attachment provides better retention and aesthetics, less resorption of the alveolar ridge, improved masticatory efficiency and relevant gain in comfort and confidence to the denture wearer, within a low financial commitment.

Further studies are needed to clarify how implants and pillar teeth behave in the long term, what the best location for implants are, and the best attachments to be used.

\section{CONCLUSION}

Alternative treatment possibilities, when well indicated and executed, may be of great value to solve therapeutic problems and meet the patient's expectations, as this case report demonstrates. By using a RPD combined with an implant-supported attachment we were able to improve the oral conditions beyond those offered by a traditional denture, not only in the biomechanical aspects, but also restoring the patient's self-esteem and quality of life, which should always be the aim of a careful dentistry.

\section{REFERENCES}

1. Silva MAB, Consani RLX, Oliveira GJPL, Reis JIL, Fontanari LA, Reis JMSN. Association between implants and removable partial dentures: review of the literature. Rev Sul Bras Odontol. 2011;8(1):88-92.

2. Memari Y, Geramy A, Fayaz A, Rezvani Habib Abadi S, Mansouri Y. Influence of Implant Position on Stress Distribution in implant-assisted distal extension removable partial dentures: a 3D finite element analysis. J Dent (Tehran). 2014;11(5):523-30.

3. Aquino ARL, Sousa SA, Carreiro AFP, Germano AR, Mendonça SL, Holanda DVM. Implant-supported removable partial denture. Rev Gaúcha Odontol. 2013;61(1):127-32.

4. Mijiritsky E, Karas S. Removable partial denture design involving teeth and implants as an alternative to unsuccessful fixed implant therapy: a case report. Implant Dent. 2004;13(3):218-22.

5. Brudvik JS. Implants and removable partial dentures. In: Advanced removable partial dentures. Chicago: Quintessence; 1999. p. 153-9.

6. Manderson RD, Wills DJ, Picton DCA. Biomechanics of denture-supporting tissues. In: Lefkowitz W (Ed.). Proceedings of the Second International Prosthodontic Congress. St. Louis: Mosby; 1979. p. 98-101.

7. Ritchie GM. Partial denture design. 3. Maxillary free-end saddle dentures. Dent Update. 1982;9(9):493-4, 496-7, 499.

8. Kuzmanovic DV, Payne AG, Purton DG. Distal implants to modify the Kennedy classification of a removable partial denture: a clinical report. J Prosthet Dent. 2004;92(1):8-11. doi: 10.1016/Soo22391304002252.

9. Verri FR, Pellizzer EP, Rocha EP, Pereira JA. Influence of length and diameter of implants associated with distal extension removable partial dentures. Implant Dent. 2007;16(3):270-80. doi: 10.1097/ID.obo13e31805007aa.

10. Gonçalves TM, Campos CH, Gonçalves GM, Moraes M, Rodrigues Garcia RC. Mastication improvement after partial implant-supported prosthesis use. J Dent Res. 2013;92 (Suppl 12):189S-94S. doi: 10.1177/0022034513508556. 